nary results designed to test the various assumptions made in the thermodynamic theory of the Volta effect. The critical analysis of these assumptions given by Koenig ${ }^{15}$ was closely followed. The results were obtained using a vibrating plate electrometer and depended on measuring the compensation potential at the air/electrolyte solution interface in the presence and absence of various spread monolayers. The variation with applied field of the true surface potential $(\Delta \chi)$ for some phospholipid monolayers in the zwitterionic form was shown to cast doubt on the general validity of the Bridgman assumption. Within experimental error, the compensation potential does not vary with the separation of the vibrating plate and the solution surface. The Lorentz-Kelvin and Kelvin assumptions though not directly disproved can only be fortuitously correct in particular cases. Tentative proposals for the orientation of water molecules at the solution surface were made.

D. A. HAYDoN

R. H. OTTEWILL
1 Frumkin, Uspekhi Khimii, 4, 938 (1935).

'Stillinger and Kirkwood, J. Chem. Phys., 33, 1282 (1960); Buff and tillinger, 39,1911 (1963).

${ }^{3}$ Levich and Krylov, Doklady Akad. Nauk, 141, 1403 (1961). Krylov and Levich, Zhur. Fiz. Khim., 37, 106 (1963). Krylov, Electrochimica Acta, 9, 247 (1964).

1 de Boer, Electron Emission and Adsorption Phenomena (Cambridge University Press, 1935).

${ }^{5}$ Esin and Shikov, Zhur. Fiz. Khim., 17, 236 (1943).

Ershler, Zhur Fiz. Khim., 20, 679 (1946).

"Grahame, Z. Elektrochem., 62, 264 (1958).

${ }^{8}$ Levich, Kiryanov and Krylov, Doklady Akad. Nauk, 135, 1425 (1960), Levich and Krylov, 142, 123 (1962); Krylov, 144, 155 (1962).

${ }^{9}$ Levine, Bell and Calvert, Can. J. Chem., 40,518 (1962). Levine and Bell; J. Phys. Chem., 67, 1408 (1963). Levine, Mingins and Bell, 67, 2095 (1963).

${ }^{10}$ Macdonald and Barlow, J. Chem. Phys., 36, 3062 (1962); 39, 412 (1963); 40, 1535 (1964).

11 Overbeek, Kolloid-Beih., 54, 287 (1943).

12 Booth, Proc. Roy. Soc., A, 203, 514 (1950).

${ }^{13}$ Wiersema, doctoral thesis, Utrecht (1964).

${ }^{14}$ Bikerman, Kolloid-Z., 72, 100 (1935).

${ }^{15}$ Koenig, C.R. Third Réunion, Com. Intern. Thermodyn, Cinet. Electrochem., 299 (1951).

\title{
NEW BRITISH ANTARCTIC BASE
}

A SMALL scientific exploration team from the British Antarctic Survey base at Halley Bay has established a research base in unexplored territory 170 miles south of Halley Bay and about 800 miles from the South Pole.

Sir Vivian Fuchs, director of the British Antarctic Survey, who led the Transantarctic Expedition in 1955, stated recently in London that: "This journey into entirely new territory has not only made possible a valuable contribution to ionospheric studies, but has paved the way for a future journey to link up our mapping programme with the work done further south by the Transantarctic Expedition".

The six-man team, led by Dr. G. Bowra, field leader, and Mr. W. Bellchambers, chief scientist, have established themselves at $77^{\circ} 57^{\prime} \mathrm{S} ., 24^{\circ} 48^{\prime} \mathrm{W}$, and have set up an ionosonde to measure the height and density of electrons in the ionosphere between 60 and 250 miles above the surface. Their main object will be to measure the drift of electron clouds over the Antarctic.

The new station, which will be a summer base, was reached after a difficult and hazardous 13-day journey over the ice field in two snow tractors, towing sledges. One of the sledges carried a 'caboose' housing scientific equipment. The equipment is powered by light-weight Villiers 'Mini-Gen' generators, giving about $1 \mathrm{~kW}$ of power.

Mr. Bellchambers heads a team of young scientists, mainly from the University College of Aberystwyth, who are spending two years in Antaretica as part of the British contribution to international research during 1964-65 (designated International Years of the Quiet Sun).

The area in which the British team is working is of particular scientific interest because it is at a very high geographic latitude (so that the Sun does not set for several months in the Antarctic summer) but at a low magnetic latitude. This means that the relation between the ionosphere, the magnetic perturbations, the aurora and the meteorology of the high atmosphere are relatively simple. Such extreme relations between these factors are not found elsewhere in the world.

The Halley Bay equipment for studying the ionosphere includes ionospheric absorption measuring equipment belonging to the Department of Scientific and Industrial Research, an ionosonde and other equipment, some of which is used in co-operation with the United States base at the South Pole.

The team which established the new base consists of: Dr. G. Bowra, field leader and medical officer, Springfield, Ashted Park, Ashted, Surrey; Mr. W. Bellchambers, senior scientist, 40 Hilltop Road, Whyteleafe, Surrey; Mr. L. Dicken, physicist, Dunedin, 18 Risca Road, Rogerston, Newport, Mon.; Mr. P. C. Goodwin, meteorologist, Haughton House, Humshaugh, Hexham, Northumberland; Mr. G. A. Thompson, tractor driver-mechanic, Hope House Cottage, Ettrick, Selkirkshire, Scotland; Mr. B. Kraehenbuehl, Angaston, South Australia.

\section{GEOLOGICAL EXPEDITION TO CAPES DYER AND SEARLE, BAFFIN ISLAND, CANADA}

\author{
By Prof. J. TUZO WILSON, O.B.E.*, and D. B. CLARKE \\ Institute of Earth Sciences and Department of Geological Sciences, University of Toronto
}

\begin{abstract}
THE occurrence of Upper Cretaceous and early Tertiary lava flows and sedimentary beds on the Atlantic coasts of Scotland, East and West Greenland, and of similar, but younger, rocks on intervening islands led to the expectation that such rocks might be found in North America1. Small patches of Tertiary sedimentary rocks have long been known on the coasts of Ellesmere Island and Northern Baffin Island ${ }^{2}$. In 1952, flat-lying

* Present address: Churchill College, Cambridge.
\end{abstract}

lavas of undetermined age were photographed at Cape Searle at latitude $67^{\circ} 12^{\prime}$ north on the east coast of Baffin Island ${ }^{3}$. They were later briefly described 4 .

This discovery has special significance in view of $\mathrm{A}$. Wegener's hypothesis ${ }^{5}$ that Greenland and northern Canada were separated by the spread of Baffin Bay accompanied by transcurrent faulting along the straits between Ellesmere Island and northern Greenland, and J. T. Wilson's corollary suggestion ${ }^{6}$ that a branch of the 